\title{
COMPARISON OF OPTIC NERVE HEAD MORPHOLOGY IN PATIENTS WITH PRIMARY OPEN ANGLE GLAUCOMA AND NON-ARTERITIC ANTERIOR ISCHEMIC OPTIC NEUROPATHY
}

\author{
Darija Jurišićc ${ }^{1}$, Katia Novak Lauš Irena Sesar $^{1}$ and Tomislav Kuzman ${ }^{3}$ \\ ${ }^{1}$ Clinical Department of Ophthalmology, Mostar University Hospital, Mostar, Bosnia and Herzegovina; \\ ${ }^{2}$ Clinical Department of Ophthalmology, Sestre milosrdnice University Hospital Center; \\ ${ }^{3}$ Clinical Department of Ophthalmology, Zagreb University Hospital Center, Zagreb, Croatia
}

SUMMARY - The aim of this study was to assess damage to retinal ganglion cells (RGC) and morphology of the optic nerve head (ONH) in patients with primary open angle glaucoma (POAG) and non-arteritic anterior ischemic optic neuropathy (NAION). The study included three groups of patients, as follows: 40 eyes with POAG, 40 eyes with NAION and 40 eyes with refraction anomaly. All patients underwent standard automated perimetry and analysis of $\mathrm{ONH}$ topography by using confocal scanning laser ophthalmoscopy (CSLO)-HRT II. Visual field defects such as decreased retinal sensitivity prevailed in the eyes with POAG, whereas in the eyes with NAION they were mostly manifested as concentrically narrowed visual field and quadrant excesses. Topographic $\mathrm{ONH}$ alterations, examined by HRT II, showed the same number of sectors to be affected in the eyes with POAG and NAION. A larger number of sectors in the upper part of ONH were affected in the eyes with NAION. Optic disc morphology differed significantly between the eyes with POAG and NAION by a higher rate of neuroretinal rim thinning and higher mean cup depth in the POAG group.

Key words: Glaucoma, open-angle; Optic neuropathy, ischemic; Optic disk; Visual field tests; Ophthalmoscopy - methods

\section{Introduction}

The most common diseases that cause damage to retinal ganglion cells (RGC) are primary open angle glaucoma (POAG) and non-arteritic anterior ischemic optic neuropathy (NAION) ${ }^{1}$. POAG is a slowly progressing bilateral chronic optic neuropathy characterized by RGC loss and morphological changes in the optic nerve head $(\mathrm{ONH})$ with thinning of the neuroretinal rim and enlargement of the optic disc cup. Histologic studies have shown the nerve fibers of greater

Correspondence to: Darija Jurišic, $M D, P h D$, Clinical Department of Ophthalmology, Mostar University Hospital, Bijeli brijeg bb, 88000 Mostar, Bosnia and Herzegovina

E-mail: jurisicd2@gmail.com

Received August 24, 2016, accepted September 28, 2016 diameter to decay more rapidly than those with a mean diameter and this loss of large axons is most common in the inferior and superior poles of the optic disc $\mathrm{d}^{2-5}$. Studies have demonstrated that mechanical stress could cause physical alterations in the $\mathrm{ONH}$, such as misalignment of the fenestrate in lamina cribrosa, which may lead to axoplasmic flow obstruction due to its back bowing. This hypothesis is supported by the observation that elevated intraocular pressure (IOP) leads to blockage of axoplasmic transport despite intact $\mathrm{ONH}$ capillary circulation and increased arterial partial oxygen pressure. It has been established that not only simple mechanical but also hydrostatic mechanisms are involved in the obstruction of axoplasmic flow as a response to elevated IOP. Ischemic lesions in POAG develop despite longitudinal and transverse 
connection of blood vessels in the ONH. These observations lead to a conclusion that POAG and NAION have a vasogenic basis of ONH damage, which is different according to the change rate ${ }^{6-8}$. The morphology of disc in POAG is characterized by thinning of the neuroretinal rim, excavation of the optic cup, and a higher cup/disc ratio ${ }^{9,10}$.

Non-arteritic anterior ischemic optic neuropathy is the most common acute unilateral optic neuropathy in persons over the age of 50. Small papilla with a small or absent physiological cup is usual in patients with NAION. It is postulated that NAION is an ischemic injury of the $\mathrm{ONH}$, which results from perfusion insufficiency in the short posterior ciliary arteries. Apart from vascular factors, there also are structural and mechanical factors that may contribute to $\mathrm{ONH}$ damage. However, NAION is considered as a multifactorial disorder, although numerous studies revealed that the crowded disc and its excavation were more important risk factors than ischemia ${ }^{11-15}$. Unlike POAG, NAION is characterized by optic disc swelling with resolution over weeks, visual field defects, morphological alteration, pallor of the optic disc, and relatively preserved neuroretinal rim.

Some general similarities in optic disc morphology are often observed in glaucomatous and NAION eyes, such as the expansion of the optic disc cup and reduction of the retinal nerve fiber layer (RNFL) thickness ${ }^{1}$. However, differences in visual field loss due to RGC damage suggest that there are distinct mechanisms of development and distribution of ischemia. The loss of nerve fibers in NAION primarily affects the superior half, whereas in POAG it usually affects temporal and inferior parts of the $\mathrm{ONH}^{16,17}$.

Relying on previous investigations, we wanted to evaluate functional and morphological damage to the $\mathrm{ONH}$ in patients with POAG and NAION.

\section{Patients and Methods}

Three groups of patients aged 50-75 were included in the study. There were 40 eyes with POAG, 40 eyes with NAION, and 40 eyes with refractive errors. All patients were selected randomly at the time of their regular ophthalmologic examination. The study was conducted between March 2015 and May 2016 at the Clinical Department of Ophthalmology, Mostar University Hospital, Mostar, Bosnia and Herzegovina. All participants provided their informed consent to be included in the study, according to the Declaration of Helsinki. The study was approved by the Hospital Ethics Committee.

The patients underwent complete ophthalmological examination that included assessment of visual acuity, examination of anterior eye segment, applanation tonometry, pachymetry, gonioscopy, and dilated fundus examination. Standard automated perimetry was done by using Humphrey Visual Field Analyzer (Carl Zeiss Meditec, Inc., Germany); 30-2 Swedish Interactive Threshold Algorithm (SITA) - standard strategy. Only reliable results with less than $20 \%$ fixation loss and fewer than 33\% of false-negative or falsepositive errors were included.

Morphological appearance of the $\mathrm{ONH}$ was defined by using the confocal scanning laser ophthalmoscopy (CSLO) on a Heidelberg Retinal Tomograph (HRT) II apparatus (Heidelberg Engineering GmbH, Heidelberg, Germany). HRT II enables three-dimensional laser scanning of the ONH. It offers global papillary morphometric parameters, and for each of six sectors dividing the papilla it compares the results with a normative database. For each patient, three topographic images were obtained, combined, and automatically aligned to create one mean topographic image used for analysis. A single examiner outlined the $\mathrm{ONH}$ border on the mean topographic image. Only good quality images with standard deviation $<50 \mu \mathrm{m}$ were included in the study.

Primary open angle glaucoma was diagnosed by the criteria of Foster et al., which means that patients had open iridocorneal angle by gonioscopy, thinning of the neuroretinal rim and visual field defects ${ }^{18}$. Visual field loss was defined as glaucoma hemifield test result outside the normal limits and three points abnormal at the $5 \%$ level in one hemifield on the pattern deviation plot of a Humphrey Visual Field Analyzer. Diagnosis of NAION was based on the history of sudden vision loss, disc pallor on fundus ophthalmoscopy, visual field defects consistent with NAION, and no signs or symptoms in medical history suggestive of arteritic anterior ischemic optic neuropathy (AAION). The third group consisted of patients with refractive error and no abnormal findings on complete ophthalmological examination, including best corrected visual acuity 
equal to or more than 0.8 , IOP less than $21 \mathrm{~mm} \mathrm{Hg}$, normal slit-lamp and fundus examination, and normal HRT II and visual field test.

The following inclusion criteria were to be met for the study purposes: 1) eyes with best corrected visual acuity 0.2 or larger; 2 ) eyes with a refraction error less than 5 and astigmatism less than 3 diopters; 3 ) history of acute NAION occurrence no more than 4 months prior to the study; 4) eyes with normal disc area (1.69$2.82 \mathrm{~mm}^{2}$ ); and 5) subjects with reliable test results of visual field and HRT II. The following exclusion criteria were applied: blurred optic media, narrowed iridocorneal angle, previous eye surgeries, and severe eye trauma.

Visual field tests were divided into six categories: no abnormality, decreased retinal sensitivity, paracentral scotoma, concentrically narrowed visual field, arch scotoma, and quadrant irregularities. The visual field parameters analyzed were mean deviation (MD) and pattern standard deviation (PSD). The following HRT II parameters were analyzed: 1) irregularities by the number of sectors; 2) irregularities by localization (T - temporal, TS - temporal superior, TI - temporal inferior, N - nasal, NS - nasal superior, NI - nasal inferior sector); 3) disc area; 4) rim area; and 5) mean cup depth.

\section{Statistical analysis}

In order to carry out statistical analysis of the data collected, the following statistical tests were selected depending on the type of variables. Median and interquartile range were selected to presenting mean values and dispersion measures in continuous variables because their distributions were significantly different from normal. Mann-Whitney U test was used to compare two such variables, whereas Kruskal-Wallis test was used to compare variables among 3 and more groups. Nominal and ordinal variables were analyzed by using the $\chi^{2}$-test. The module of exact tests was used for deficiency of the expected frequency. The values of $p$ less than 0.05 were considered to be statistically significant. All statistical analyses were performed

Table 1. Visual field defect characteristics in patients with $P O A G, N A I O N$ and refractive errors

\begin{tabular}{|c|c|c|c|c|c|}
\hline \multirow[b]{2}{*}{ Visual field } & \multicolumn{3}{|c|}{ Number (\%) of patients } & \multirow[b]{2}{*}{$\chi^{2}$-test } & \multirow[b]{2}{*}{$\mathrm{p}$} \\
\hline & $\begin{array}{l}\text { Patients } \\
\text { with POAG }\end{array}$ & $\begin{array}{l}\text { Patients } \\
\text { with NAION }\end{array}$ & Control group & & \\
\hline $\begin{array}{l}\text { No abnormality } \\
\text { Yes } \\
\text { No }\end{array}$ & $\begin{array}{l}3(7.5) \\
37(92.5)\end{array}$ & $\begin{array}{l}0 \\
40(100.0)\end{array}$ & $\begin{array}{l}34(94.4) \\
2(5.6)\end{array}$ & 94.530 & $<0.001$ \\
\hline $\begin{array}{l}\text { Decreased retinal sensitivity } \\
\text { Yes } \\
\text { No }\end{array}$ & $\begin{array}{l}9(22.5) \\
31(77.5)\end{array}$ & $\begin{array}{l}5(12.5) \\
35(87.5)\end{array}$ & $\begin{array}{l}0 \\
40(100.0)\end{array}$ & $11.033^{*}$ & 0.003 \\
\hline $\begin{array}{l}\text { Paracentral scotoma } \\
\text { Yes } \\
\text { No }\end{array}$ & $\begin{array}{l}5(12.5) \\
35(87.5)\end{array}$ & $\begin{array}{l}6(15.0) \\
34(85.0)\end{array}$ & $\begin{array}{l}1(2.5) \\
39(97.5)\end{array}$ & $4.157^{*}$ & 0.149 \\
\hline $\begin{array}{l}\text { Concentrically narrowed visual field } \\
\text { Yes } \\
\text { No }\end{array}$ & $\begin{array}{l}3(7.5) \\
37(92.5)\end{array}$ & $\begin{array}{l}5(12.5) \\
35(87.5)\end{array}$ & $\begin{array}{l}0 \\
40(100.0)\end{array}$ & $5.323^{*}$ & 0.095 \\
\hline $\begin{array}{l}\text { Arch scotoma } \\
\text { Yes } \\
\text { No }\end{array}$ & $\begin{array}{l}12(30.0) \\
28(70.0)\end{array}$ & $\begin{array}{ll}11 & (27.5) \\
29 & (72.5)\end{array}$ & $\begin{array}{l}1(2.5) \\
39(97.5)\end{array}$ & 11.563 & 0.003 \\
\hline $\begin{array}{l}\text { Quadrant excesses } \\
\text { Yes } \\
\text { No }\end{array}$ & $\begin{array}{l}8(20.0) \\
32(80.0)\end{array}$ & $\begin{array}{l}13(32.5) \\
27(67.5)\end{array}$ & $\begin{array}{l}0 \\
40(100.0)\end{array}$ & 14.892 & 0.001 \\
\hline
\end{tabular}

*Exact test; POAG = primary open angle glaucoma; NAION = non-arteritic anterior ischemic optic neuropathy 


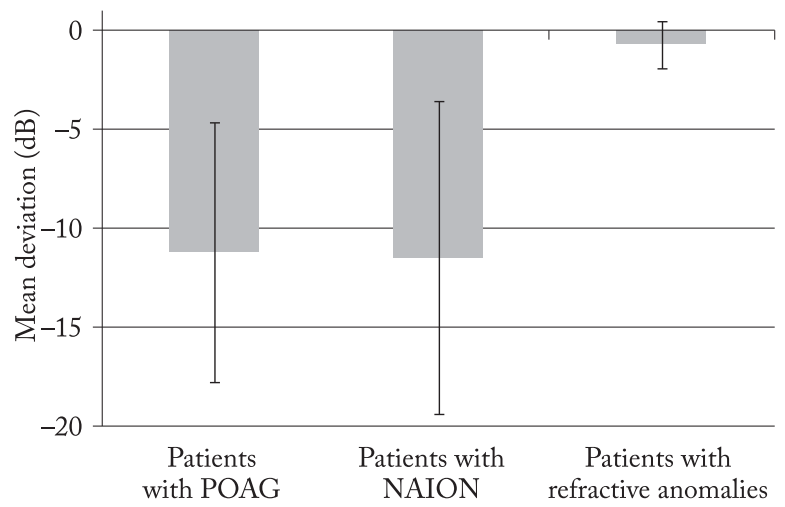

$\mathrm{MD}=$ mean deviation; $\mathrm{POAG}=$ primary open angle glaucoma; NAION $=$ non-arteritic anterior ischemic optic neuropathy

Fig. 1A. Comparison of visual field mean deviation among three patient groups.

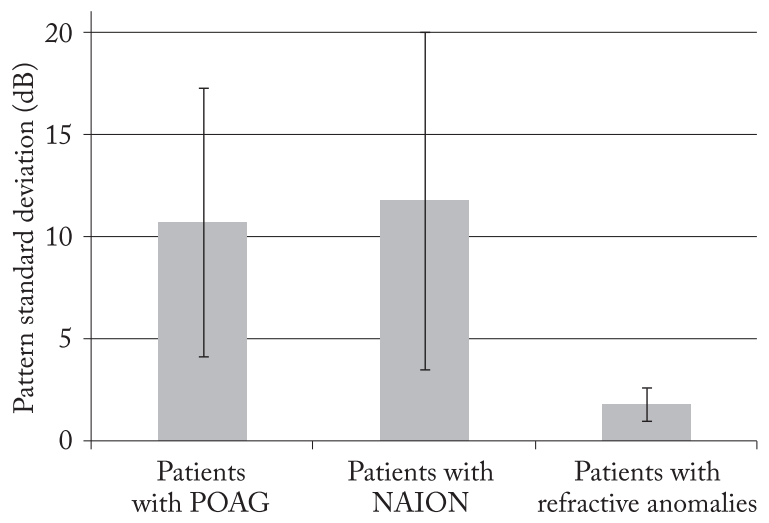

$\mathrm{PSD}=$ pattern standard deviation; $\mathrm{POAG}=$ primary open angle glaucoma; NAION = non-arteritic anterior ischemic optic neuropathy

Fig. 1B. Comparison of visual field pattern standard deviation among three patient groups.

using the SPSS v. 20.0 package (SPSS Inc., Chicago, Illinois, USA).

\section{Results}

\section{Visual field defect characteristics}

The loss of RGC was estimated by evaluating the visual field defect characteristics in patients with POAG and NAION (Table 1). The visual field parameters of MD and PSD were analyzed. In patients with POAG, visual field irregularities in the form of decreased retinal sensitivity $(22.5 \%)$ prevailed. This value was significantly higher in comparison with patients with NAION and control group. In patients with NAION, visual field defects were mostly manifested as a concentrically narrowed visual field (12.5\%) and quadrant irregularities (32.5\%). These percentages of visual field damage were significantly higher in comparison with the two other groups.

\section{Comparison of visual field mean deviation and pattern standard deviation}

Comparison of visual field defects expressed as $\mathrm{MD}$ and PSD was done among three groups of patients: POAG, NAION and controls (refractive anomalies) (Fig. 1). The value of MD was -11.165 [6.55] $\mathrm{dB}$ in patients with POAG, -11.430 [7.88] dB in patients with NAION, and -0.705 [1.16] dB in control group (Kruskal-Wallis test=69.642; $\mathrm{p}<0.001$ ). MD value was significantly higher in the group of patients with NAION in comparison with control group (Mann-Whitney U test=2.500; $\mathrm{p}<0.001$ ). Also, statistical analysis showed the MD value to be significantly higher in patients with POAG than in control group (Mann-Whitney U test=100.000; $\mathrm{p}<0.001$ ) (Fig. 1A).

The value of PSD was 10.700 [6.57] dB in patients with POAG, 11.770 [8.24] $\mathrm{dB}$ in patients with NAION, and 1.805 [0.82] dB in control group (Kruskal-Wallis test=72.780; $\mathrm{p}<0.001)$. The value of PSD in the POAG group (Mann-Whitney U test=53.000; $\mathrm{p}<0.001$ ) and NAION group (Mann-Whitney U test=21.000; $\mathrm{p}<0.001)$ was significantly higher in comparison to control group (Fig. 1B).

\section{Characteristics of the optic nerve head sectors on HRT II}

We estimated the loss of RGC and topographic changes of $\mathrm{ONH}$ according to the number and localization of affected sectors by using HRT II. Patients with NAION had a significantly higher number of excesses in three sectors (22.5\%), whereas patients with NAION and POAG had significantly higher excesses in four $(27.5 \%$ and $30.0 \%)$ and five sectors (35.0\%), respectively, in comparison to control group (Table 2).

In patients with POAG, the localization of irregularities on HRT II was significantly higher in the temporal inferior (87.5\%), nasal (70.0\%) and nasal inferior sector $(57.5 \%)$, whereas patients with NAION mostly 
Table 2. Number of affected sectors using HRT II in patients with POAG, NAION and refractive errors

\begin{tabular}{|c|c|c|c|c|c|}
\hline \multirow[b]{2}{*}{$\begin{array}{l}\text { Number of sectors } \\
\text { with excess }\end{array}$} & \multicolumn{3}{|c|}{ Number (\%) of patients } & \multirow[b]{2}{*}{$\chi^{2}$-test } & \multirow[b]{2}{*}{$\mathrm{p}$} \\
\hline & $\begin{array}{l}\text { Patients } \\
\text { with POAG }\end{array}$ & $\begin{array}{l}\text { Patients } \\
\text { with NAION }\end{array}$ & Control group & & \\
\hline $\begin{array}{l}\text { No abnormality } \\
\text { Yes } \\
\text { No }\end{array}$ & $\begin{array}{l}3(7.5) \\
37(92.5)\end{array}$ & $\begin{array}{l}0 \\
40(100.0)\end{array}$ & $\begin{array}{l}34(85.0) \\
6(15.0)\end{array}$ & 83.074 & $<0.001$ \\
\hline $\begin{array}{l}\text { One sector } \\
\text { Yes } \\
\text { No }\end{array}$ & $\begin{array}{l}0 \\
40(100.0)\end{array}$ & $\begin{array}{l}0 \\
40(100.0)\end{array}$ & $\begin{array}{l}0 \\
40(100.0)\end{array}$ & $\mathrm{NS}^{*}$ & \\
\hline $\begin{array}{l}\text { Two sectors } \\
\text { Yes } \\
\text { No }\end{array}$ & $\begin{array}{l}4(10.0) \\
36(90.0)\end{array}$ & $\begin{array}{l}5(12.5) \\
35(87.5)\end{array}$ & $\begin{array}{l}1(2.5) \\
39(97.5)\end{array}$ & $2.942^{* *}$ & 0.339 \\
\hline $\begin{array}{l}\text { Three sectors } \\
\text { Yes } \\
\text { No }\end{array}$ & $\begin{array}{l}3(7.5) \\
37(92.5)\end{array}$ & $\begin{array}{l}9(22.5) \\
31(77.5)\end{array}$ & $\begin{array}{l}0 \\
40(100.0)\end{array}$ & $11.400^{* * *}$ & 0.002 \\
\hline $\begin{array}{l}\text { Four sectors } \\
\text { Yes } \\
\text { No }\end{array}$ & $\begin{array}{ll}12 & (30.0) \\
28 & (70.0)\end{array}$ & $\begin{array}{l}11(27.5) \\
29(72.5)\end{array}$ & $\begin{array}{l}0 \\
40(100.0)\end{array}$ & 14.307 & 0.001 \\
\hline $\begin{array}{l}\text { Five sectors } \\
\text { Yes } \\
\text { No }\end{array}$ & $\begin{array}{l}14(35.0) \\
26(65.0)\end{array}$ & $\begin{array}{l}14(35.0) \\
26(65.0)\end{array}$ & $\begin{array}{l}1(2.5) \\
39(97.5)\end{array}$ & 15.369 & $<0.001$ \\
\hline $\begin{array}{l}\text { Six sectors } \\
\text { Yes } \\
\text { No } \\
\end{array}$ & $\begin{array}{l}4(10.0) \\
36(90.0)\end{array}$ & $\begin{array}{l}1(2.5) \\
39(97.5)\end{array}$ & $\begin{array}{l}0 \\
40(100.0)\end{array}$ & $4.394^{* *}$ & 0.125 \\
\hline
\end{tabular}

*No statistics; **exact test; HRT II = Heidelberg retinal tomograph II; POAG = primary open angle glauco$\mathrm{ma} ; \mathrm{NAION}=$ non-arteritic anterior ischemic optic neuropathy

had irregularities in the temporal (65.0\%), temporal superior (100\%) and nasal superior sector (85.0\%) (Table 3).

\section{Neuroretinal rim area}

Measurements of the neuroretinal rim area of $\mathrm{ONH}$ were done by HRT II and expressed in $\mathrm{mm}^{2}$. It was $0.911[0.320] \mathrm{mm}^{2}$ in patients with POAG, 1.529 [0.283] $\mathrm{mm}^{2}$ in patients with NAION and 1.581 [0.453] $\mathrm{mm}^{2}$ in control group (Kruskal-Wallis test= 51.951; $\mathrm{p}<0.001$ ) (Fig. 2). Statistical analysis showed the neuroretinal rim area in POAG group to be significantly lower as compared with the other two groups, NAION group (Mann-Whitney U test $=171.000$; $\mathrm{p}<0.001$ ) and control group (Mann-Whitney U test= 149.000; $\mathrm{p}<0.001)$.

\section{Mean cup depth}

The HRT II was used to measure the mean cup depth of ONH (Fig. 3). In patients with POAG, the mean cup depth was 0.346 [0.156] $\mathrm{mm}$ and it was significantly higher than in patients with NAION (0.174 [0.021] mm; Mann-Whitney U test=161.000; $\mathrm{p}<0.001)$ and control group (0.159 [0.148] mm; Mann-Whitney $U$ test=169.000; $\mathrm{p}<0.001)$.

\section{Discussion}

Several studies compared optic disc morphology in patients with POAG and NAION at a given level of RGC loss and the authors focused on global ONH parameters ${ }^{16,17,19}$. In our study, we estimated global and sector $\mathrm{ONH}$ parameters and visual field defects in or- 
Table 3. Localization of affected sectors using HRT II in patients with POAG, NAION and refractive errors

\begin{tabular}{|c|c|c|c|c|c|}
\hline & \multicolumn{3}{|c|}{ Number (\%) of patients } & \multirow[b]{2}{*}{$\chi^{2}$-test } & \multirow[b]{2}{*}{$\mathrm{p}$} \\
\hline & $\begin{array}{l}\text { Patients } \\
\text { with POAG }\end{array}$ & \begin{tabular}{|l} 
Patients \\
with NAION
\end{tabular} & \begin{tabular}{|l|} 
Control \\
group
\end{tabular} & & \\
\hline $\begin{array}{l}\text { Temporal sector } \\
\text { Yes } \\
\text { No }\end{array}$ & $\begin{array}{ll}11 & (27.5) \\
29 & (72.5)\end{array}$ & $\begin{array}{ll}26 & (65.0) \\
14 & (35.0) \\
\end{array}$ & $\begin{array}{l}0 \\
40(100.0) \\
\end{array}$ & 39.935 & $<0.001$ \\
\hline $\begin{array}{l}\text { Temporal superior sector } \\
\text { Yes } \\
\text { No }\end{array}$ & $\begin{array}{l}35(87.5) \\
5(12.5)\end{array}$ & $\begin{array}{l}40(100.0) \\
0\end{array}$ & $\begin{array}{l}1(2.5) \\
39(97.5)\end{array}$ & 96.962 & $<0.001$ \\
\hline $\begin{array}{l}\text { Temporal inferior sector } \\
\text { Yes } \\
\text { No }\end{array}$ & $\begin{array}{l}35(87.5) \\
5(12.5)\end{array}$ & $\begin{array}{ll}15 & (37.5) \\
25 & (62.5)\end{array}$ & $\begin{array}{l}2(5.0) \\
38(95.0)\end{array}$ & 56.267 & $<0.001$ \\
\hline $\begin{array}{l}\text { Nasal sector } \\
\text { Yes } \\
\text { No }\end{array}$ & $\begin{array}{l}28(70.0) \\
12(30.0)\end{array}$ & $\begin{array}{ll}25 & (62.5) \\
15 & (37.5)\end{array}$ & $\begin{array}{l}1(2.5) \\
39(97.5)\end{array}$ & 44.242 & $<0.001$ \\
\hline $\begin{array}{l}\text { Nasal superior sector } \\
\text { Yes } \\
\text { No }\end{array}$ & $\begin{array}{l}26(65.0) \\
14(35.0)\end{array}$ & $\begin{array}{l}34(85.0) \\
6(15.0)\end{array}$ & $\begin{array}{l}1(2.5) \\
39(97.5)\end{array}$ & 59.283 & $<0.001$ \\
\hline $\begin{array}{l}\text { Nasal inferior sector } \\
\text { Yes } \\
\text { No }\end{array}$ & $\begin{array}{l}23(57.5) \\
17(42.5)\end{array}$ & $\begin{array}{l}17(42.5) \\
23(57.5)\end{array}$ & $\begin{array}{l}2(5.0) \\
38(95.0)\end{array}$ & 25.714 & $<0.001$ \\
\hline
\end{tabular}

HRT II = Heidelberg retinal tomograph II; POAG = primary open angle glaucoma; NAION = non-arteritic anterior ischemic optic neuropathy

der to differentiate glaucoma and ischemic optic neuropathy. In patients with POAG, visual field irregularities in the form of decreased retinal sensitivity prevailed, similar to those described in the study by Mills et $a .^{20}$. According to the classification proposed by Hodapp et al. ${ }^{21}$, all examined patients with POAG had early or moderately developed disease. In patients with NAION, visual field defects were mostly manifested as a concentrically narrowed visual field and quadrant excess, and similar results were obtained by Tesser et al..$^{22}$.

Patients with POAG and NAION had significantly higher MD and PSD values in comparison to control group, while there was no significant difference between the groups of patients with POAG and NAION. The studies by Saito et al. and Danesh-Meyer et al. showed almost similar MD and PSD results by comparison of POAG and NAION patients ${ }^{16,17}$. Mayama et al.also found that visual field defects in patients with glaucoma, expressed as MD or PSD value, were significantly higher than in healthy controls ${ }^{23}$. According to some studies, MD was a more relevant parameter than PSD value ${ }^{24}$.

By using HRT II in order to analyze ONH topography, we showed that patients with POAG had a significantly higher number of excesses in four and five sectors, whereas patients with NAION had more excesses in three, four and five sectors. According to localization, in patients with POAG irregularities prevailed in the temporal inferior, nasal and nasal inferior sector. In NAION patients, irregularities were mostly located in the temporal superior, temporal and nasal superior sector.In this study, patients with POAG had the same number but different localization of affected $\mathrm{ONH}$ sectors in comparison to NAION patients for the same level of RGC loss, which was estimated by visual field MD. Han et al. demonstrated that the inferotemporal rim loss usually was more pronounced in glaucoma patients, and therefore superior visual field defects were more expressed. Therefore, inferior visual 


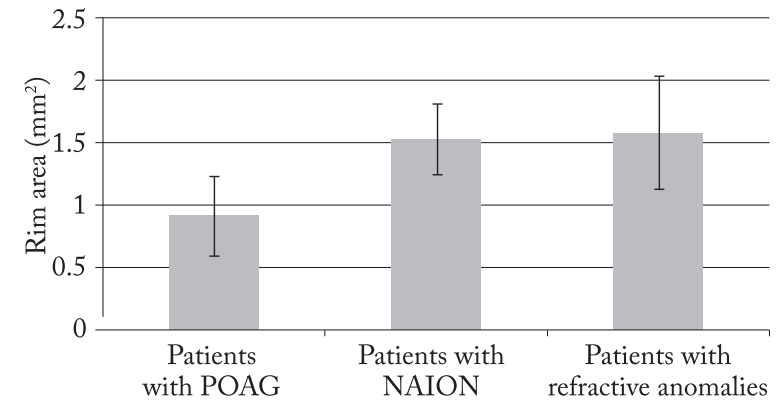

POAG $=$ primary open angle glaucoma; $\mathrm{NAION}=$ non-arteritic anterior ischemic optic neuropathy

Fig. 2. Comparison of the neuroretinal rim area among three patient groups.

field defects were more common in the NAION group $^{25}$. Other authors found thickening rather than thinning of the prelaminar neural tissue to occur first in the early stage of glaucoma. A possible explanation could be that POAG first reduces the function of RGC, whereas NAION results in acute RGC death ${ }^{1,19}$.

The predilection site of $\mathrm{ONH}$ damage in patients with POAG and NAION could be a result of impairment in the prelaminar and laminar regions, which differ by structural elements. The prelaminar region contains axons of RGC, astrocytes and glial cells, whereas the laminar region is made up from dense connective glial tissue that forms barrier around axon bundles. POAG affects the laminar connective tissue much more than NAION. Consequently, the loss of axons leads to an increase of disc excavation and thinning of the connective tissue. Unlike POAG, the neuroretinal rim is relatively spared in NAION. It is possible that difference in the structure of extracellular matrix influences the stability of laminar region. Vascular supply of $\mathrm{ONH}$ in the eyes with POAG passes vertically (60\% of cases) through temporal part of the papilla and is more sensitive to ischemia when the perfusion pressure decreases ${ }^{26,27}$. In the eyes with NAION, segmental excesses probably occur due to anatomic division of the microvasculature supplying the $\mathrm{ONH}$ into distinct upper and lower halves.

In this study, measurement of the neuroretinal rim area in patients with POAG and NAION yielded similar results as in the studies by Yang et al.,DaneshMeyer et al. and Suh et al., in which the authors compared neuroretinal rim and RNFL as a criterion for distinguishing POAG and NAION using HRT II

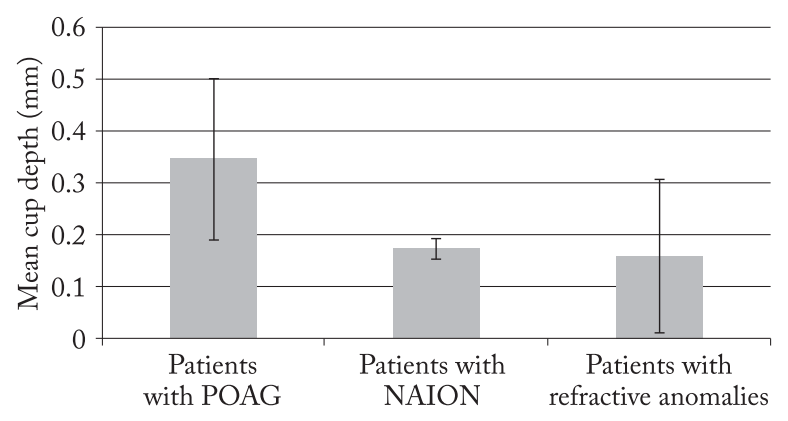

POAG $=$ primary open angle glaucoma NAION = non-arteritic anterior ischemic optic neuropathy

\section{Fig. 3. Comparison of the mean cup depth among three} patient groups.

and optical coherent tomography. They found that neuroretinal rim was mostly preserved in $\mathrm{NAION}^{1,17,19}$.

Our results showed the mean cup depth to be significantly greater in POAG patients, similar to the results reported by Mayama et al. ${ }^{23}$. Results recorded by Jonas et al. suggested that size and shape of neuroretinal rim did not change in NAION patients contrary to POAG patients, in which the loss of neuroretinal rim and widening and deepening of the optic cup occurred $^{27}$. However, it is not clear why ischemic attack in NAION eyes does not lead to significant changes of neuroretinal rim, although RGC are damaged to the same degree as in glaucoma ${ }^{28}$. Furthermore, Lee et al. found that the prelaminar tissue thickness was thinner in glaucoma patients than in NAION patients. This could be caused by reactive gliosis, which replaces loss of neural fibers in NAION patients ${ }^{26}$.

Using HRT II, Jung et al. demonstrated significant negative relationship between IOP value and prelaminar tissue thickness in glaucoma patients, indicating that the loss of neural tissue resulted in thinning of prelaminar tissue ${ }^{28}$.

Saito et al. found a significantly greater cup area and cup volume in patients with NAION than in normal eyes. It is possible that NAION eyes in the aforementioned study were investigated much later after disease onset, which could have resulted in more prone cupping $^{29}$. On the contrary, results of other studies showed that NAION patients had a smaller optic cup and cup/disc ratio ${ }^{26,30}$.

In this study, the visual field defects characteristic of POAG patients were mostly in the form of decreased retinal sensitivity, whereas in NAION patients 
they were in the form of concentrically narrowed visual field and quadrant excesses. The $\mathrm{ONH}$ topographic alterations in POAG were mostly localized in the temporal inferior, nasal and nasal inferior sector, whereas in NAION they were localized in the temporal, temporal superior and nasal superior sector. The optic disc topography differed significantly between POAG and NAION patients by the higher rate of neuroretinal rim thinning and higher mean cup depth in the eyes with POAG.

This study had potential limitations. The amount of RGC loss was adjusted by the visual field results, which are not strongly confident, particularly in NAION patients that had worse central vision acuity than POAG patients, and had no visual field testing experience as glaucoma patients. A disadvantage of the study performed with HRT II could be that the disc margin was drawn by the observer, thus introducing subjectivity into image analysis.

\section{References}

1. Yang Y, Zhang H, Yan Y, Gui Y, Zhu T. Comparison of optic nerve morphology in eyes with glaucoma and eyes with nonarteritic anterior ischemic optic neuropathy by Fourier domain optical coherence tomography. Exp Ther Med. 2013;6:268-74, doi:10.3892/etm.2013.1115

2. Tatham AJ, Weinreb RN, Zangwill LM, Liebmann JM, Girkin CA, Medeiros FA. The relationship between cup-to-disc ratio and estimated number of retinal ganglion cells. Invest Ophthalmol Vis Sci. 2013;54:3205-14, doi:10.1167/iovs.12-11467

3. Kwon YH, Fingert JH, Kuehn MH, Alward WL. Primary open-angle glaucoma. N Engl J Med. 2009;360:1113-24, doi:10.1056/NEJMra0804630

4. Novak-Lauš K, Mandić Z, Iveković R, Bojić L, Koršić J, Zorić-Geber M. Initial clinical experience with brinzolamide 1\% ophthalmic suspension (Azopt). Acta Clin Croat. 2003;42:101-4.

5. Popović-Sujić S, Kuzman T, Kordić R, Cerovski B. Is central corneal thickness a risk factor for pseudoexfoliation glaucoma? Acta Clin Croat. 2007;46(Suppl 1): 95-7.

6. Arnold AC. Pathogenesis of nonarteritic anterior ischemic optic neuropathy. J Neuroophthalmol. 2003;23:157-63.

7. Hayreh SS, Jonas JB. Optic disc morphology after arteritic anterior ischemic optic neuropathy. Ophthalmology. 2001;108: 1586-94, http://dx.doi.org/10.1016/S0161-6420(02)01144-2

8. Burgoyne CF, Downs JC, Bellezza AJ, Suh JK, Hart RT. The optic nerve head as a biomechanical structure: a new paradigm for understanding the role of IOP-related stress and strain in the pathophysiology of glaucomatous optic nerve head damage. Prog Retin Eye Res. 2005;24:39-73, doi:10.1016/j.preteyeres.2004.06.001
9. Moreno-Montanes J, Anton A, García N, Olmo N, Morilla A, Fallon M. Comparison of retinal nerve fiber layer thickness values using stratus optical coherence tomography and Heidelberg retina tomograph-III. J Glaucoma. 2009;18:528-34, doi:10.1097/IJG.0b013e318193c29f

10. Novak-Lauš K, Kukulj S, Iveković R,Tedeschi-Reiner E, Koršić J, Matanić D. Inhaled corticosteroids and the risk of glaucoma and intraocular hypertension. Acta Clin Croat. 2003; 42:41-5.

11. Punjabi OS, Tanna AP, Rosenberg MA. Optic disk excavation in nonarteritic anterior ischemic optic neuropathy. J Glaucoma. 2011;20:71-3, doi:10.1097/IJG.0b013e3181dddf5c

12. Pasol J. Neuro-ophthalmic disease and optical coherence tomography: glaucoma look-alikes. Curr Opin Ophthalmol. 2011;22:124-32, doi:10.1097/ICU.0b013e328343c1a3

13. Hayreh SS. Ischemic Optic Neuropathies. Springer Verlag, Heidelberg. 2011;298-301.

14. Chuman H. Nonarteritic ischemic optic neuropathy animal model and its treatment applications. Nippon Ganka Gakkai Zasshi. 2014;118:331-61.

15. Contreras I, Rebolleda G, Noval S, Munoz-Negrete FJ. Optic disc evaluation by optical coherence tomography in nonarteritic anterior ischemic optic neuropathy. Invest Ophthalmol Vis Sci. 2007;48:4087-92, doi:10.1167/iovs.07-0171

16. Saito H,Tomidokoro A, Sugimoto E, et al. Optic disc topography and peripapillary retinal nerve fiber layer thickness in nonarteritic ischemic optic neuropathy and open-angle glaucoma. Ophthalmology. 2006;113:1340-4, doi:10.1016/j.ophtha.2006. 01.072

17. Danesh-Meyer HV, Boland MV, Savino PJ, Miller NR, Subramanian PS, Girkin CA, et al. Optic disc morphology in openangle glaucoma compared with anterior ischemic optic neuropathies. Invest Ophthalmol Vis Sci. 2010;51:2003-10, doi: 10.1167/iovs.09-3492

18. Foster PJ, Buhrmann R, Quigley HA, et al. The definition and classification of glaucoma in prevalence surveys. $\mathrm{Br} \mathrm{J}$ Ophthalmol. 2002;86:238-42.

19. Suh MH, Kim SH, Park KH, Kim SJ, Kim TW, Hwang SS, et al. Comparison of the correlations between optic disc rim area and retinal nerve fiber layer thickness in glaucoma and nonarteritic anterior ischemic optic neuropathy. Am J Ophthalmol. 2011;151:277-86, doi:10.1016/j.ajo.2010.08.033

20. Mills RP, Budenz DL, Lee PP, Noecker RJ, Walt JG, Siegartel $\mathrm{LR}$, et al. Categorizing the stage of glaucoma from pre-diagnosis to end-stage disease. Am J Ophthalmol. 2006;141:24-30, doi:10.1016/j.ajo.2005.07.044

21. Hodapp E, Parrish RK, Andersson DR. Clinical Decisions in Glaucoma. The CV Mosby Company, St. Louis, USA, 1993.

22. Tesser RA, Niendorf ER, Levin LA. The morphology of an infarct in nonarteritic anterior ischemic optic neuropathy. Ophthalmology. 2003;110:2031-5, doi:10.1016/S0161-6420 (03)00804-2

23. Mayama C, Tsutumi T, Saito H, Asaoka R, Tomidokoro A, Iwase A, et al. Glaucoma-induced optic disc morphometric changes and glaucoma diagnostic ability of Heidelberg retina 
tomograph II in highly myopic eyes. PLoS ONE. 2014; 9:e86417, https://doi.org/10.1371/journal.pone.0086417

24. Chauhan BC, Garway-Heath DF, Gony FJ, Rosseti L, Bengtsson $\mathrm{B}$, Viswanathan AC, et al. Practical recommendations for measuring rates of visual field change in glaucoma. $\mathrm{Br} \mathrm{J} \mathrm{Oph-}$ thalmol. 2008;92:569-73, doi:10.1136/bjo.2007.135012

25. Han S, Jung JJ, Kim US. Differences between non-arteritic anterior ischemic optic neuropathy and open angle glaucoma with altitudinal visual field defect. Korean J Ophthalmol. 2015;29:418-23, doi:10.3341/kjo.2015.29.6.418

26. Lee EJ, Choi YJ, Kim TW, Hwang JM. Comparison of the deep optic nerve head structure between normal-tension glaucoma and nonarteritic anterior ischemic optic neuropathy. PLoS One. 2016;11:e0150242, https://doi.org/10.1371/journal.pone. 0150242

27. Jonas JB, Hayreh SS, Tao Y, Papasthopoulos KI, Rehsch F. Optic nerve head change in non-arteritic anterior ischemic optic neuropathy and its influence on visual outcome. PLoS ONE. 2012;7:e37499, https:// doi.org/10.1371/journal.pone.0037499

28. Jung YH, Park H-YL, Jung KI, Park CK. Comparison of prelaminar thickness between primary open angle glaucoma and normal tension glaucoma patients. PLoS ONE. 2015;10: e0120634, https://doi.org/10.1371/journal.pone.0120634

29. Saito H, Tomidokoro A, Tomita G, Ariae M, Wakakura M. Optic disc and peripapillary morphology in unilateral nonarteritic anterior ischemic optic neuropathy and age- and refraction-matched normals. Ophthalmology. 2008;115:1585-90, doi:10.1016/j.ophtha200801.012

30. Chan CK, Cheng AC, Leung CK, Cheung CY, Yung AY, Gong B, et al. Quantitative assessment of optic nerve head morphology and retinal nerve fibre layer in non-arteritic anterior ischemic optic neuropathy with optical coherence tomography and confocal scanning laser ophthalmoloscopy. Br J Ophthalmol. 2009;93:731-5, doi:10.1136/bjo.2008.143297

\section{Sažetak \\ USPOREDBA MORFOLOGIJE GLAVE VIDNOGA ŽIVCA U BOLESNIKA S PRIMARNIM GLAUKOMOM OTVORENOG KUTA I NEARTERITIČKOM ISHEMIJSKOM OPTIČKOM NEUROPATIJOM}

\section{Jurišic, K. Novak Laǔs, I. Sesar i T. Kuzman}

Svrha ovoga rada bila je utvrditi oštećenje ganglijskih stanica mrežnice i morfološke promjene glave vidnoga živca u ispitanika s primarnim glaukomom otvorenog kuta (POAG) i nearteritičkom prednjom ishemijskom optičkom neuropatijom (NAION). Prva skupina ispitanika sastojala se od 40 očiju s POAG, druga skupina od 40 očiju s NAION i treća skupina od 40 očiju s refrakcijskom anomalijom (kontrolna skupina). Svim ispitanicima napravljena je automatizirana perimetrija i analiza topografije glave vidnoga živca pomoću konfokalne skenirajuće laserske oftalmoskopije (CSLO)-HRT II. Smanjena mrežnična osjetljivost prevladavala je u bolesnika s POAG, dok su se u bolesnika s NAION defekti očitovali u obliku koncentrično suženog vidnog polja i kvadrantnih ispada. Topografske promjene glave vidnoga živca ispitivane pomoću HRT II ukazale su na to da je u bolesnika s POAG i NAION oštećen jednak broj sektora. Veći broj sektora u gornjem dijelu glave vidnoga živca bio je oštećen u bolesnika s NAION. Morfologija glave vidnoga živca značajno se razlikovala između bolesnika s POAG i NAION, pokazujući veće stanjenje neuroretinalnog ruba i veću dubinu ekskavacije u bolesnika s POAG.

Ključne riječi: Glaukom otvorenog kuta; Vidni živac, neuropatija, ishemična; Disk vidnog živca; Vidno polje, testovi; Oftalmoskopija-metode 